\title{
Dampak Pembelajaran Daring Pada Siswa Dan Guru Di Era Covid 19
}

\author{
Wandira, $\mathrm{P}^{1 *}$, Sabrina, $\mathrm{M}^{1}$, Sinaga, $\mathrm{N}^{1}$, Putri, $\mathrm{J}^{1}$ dan Nasution, $\mathrm{T}^{1}$ \\ ${ }^{1}$ Universitas Islam Negeri Sumatera Utara
}

\begin{abstract}
Abstrak-Tujuan dari penelitian ini untuk melihat bagaimana dampak dari guru dan siswa terhadap pembelajaran online selama wabah Covid-19. Penelitian ini menggunakan metodologi penelitian deskriptif kualitatif, data yang dikumpulkan melalui wawancara, dengan fokus pada pencarian data tentang masalah yang relevan. Dalam penelitian ini subyek yang dipakai oleh peneliti adalah siswa SMP di Swasta Taman Harapan Medan. Setalah dilakukan penelitian dan peneliti menemukan hasil dari penelitian yang menunjukkan bahwa proses pembelajaran yang dilakukan berubah karena harus menggunakan proses pembelajaran jarak jauh. Tentu saja pembelajaran jarak jauh memberikan dampak yang kurang maksimal karena dalam proses pemberian materi pembelajaran dan juga terganggungya proses pembelajaran antara guru dan siswa-siswi, sehingga tidak tercapainya tujuan pembelajaran yang diharapkan oleh guru dan siswa. Penilaian siswa terkendala sekedar peniliaian kognitif.

\author{
Kata kunci: \\ Dampak pembelajaran Covid \\ 19 , \\ Pembelajaran daring, \\ Siswa dan guru

\section{Histori:} \\ Direvisi: 29 September 2021 \\ Diterima: 30 September 2021 \\ Online: 30 September 2021
}

Dikirim: 13 Agustus 2021

(i) (2) Author(s) agree that this article remains permanently open access under the terms of the Creative cC)
\end{abstract}

\section{Identitas Artikel:}

Wandira, P., Sabrina, M., Sinaga, N., Putri, J., \& Nasution, T. Dampak Pembelajaran Daring Pada Siswa Dan Guru Di Era Covid 19. Jurnal Citizenship Virtues, 1(2), 151-156.

\section{PENDAHULUAN}

Kehadiran virus corona/coronavirus telah membuat heran negara kita bahkan seluruh dunia (Covid-19). Virus corona yang mulai terjadi di kota Wuhan, China, menjelang akhir Desember tahun lalu, dan meluas ke seluruh Indonesia pada awal tahun 2020. (2019). Alhasil, negara-negara tertentu telah menerapkan kebijakan untuk memberlakukan lockdown guna mencegah penyebaran virus corona. Indonesia juga menerapkan sistem PSBB, PSBB itu sendiri adalah singkatan dari "Pembatasan Sosial Berskala Besar". Hal tersebut dilakukan agar masyarakat Indonesia dapat menjaga jarak satu sama lain dan mengurangi keterlibatan satu sama lain (Agustino, 2020; Ahidin, 2020; Misno, 2020). Dengan masuknya virus corona, menjadi penghalang bagi semua kalangan di seluruh dunia, sekaligus menjadi ancaman kesehatan. Hal ini juga sangat berpengaruh terhadap dunia pendidikan. Dampak Covid-19 terhadap pendidikan sangat besar, dan dirasakan oleh berbagai kalangan, termasuk instruktur, kepala sekolah, siswa, dan orang tua. Universitas dan perguruan tinggi di seluruh dunia telah ditutup karena pandemi

\footnotetext{
${ }^{1}$ *Corresponding author.

E-mail: putriwandira21@gmail.com
} 
yang parah. (Fredy et al.,2020). Dengan ditutupnya sekolah, pemerintah telah mengambil langkah-langkah untuk memastikan bahwa pembelajaran tidak tertinggal dan anak-anak terus memiliki akses ke pengetahuan. Akibatnya, keputusan pemerintah selanjutnya adalah proses pembelajaran akan tetap berlangsung, tetapi secara online tidak tatap muka. Guru harus mampu melaksanakan proses pembelajaran online di rumah dengan baik sebagai akibat dari undang-undang ini. Agar instruktur dapat melaksanakan pembelajaran dengan percaya diri, mereka harus memiliki pengetahuan tentang teknologi informasi. (Nugrahaet al., 2020). Dalam hal kekurangan guru, Covid-19 berdampak signifikan pada siswa; Pelajaran yang dulunya diajarkan di kelas dengan jumlah siswa yang banyak kini harus berbanding terbalik dengan kondisi yang memaksa siswa untuk belajar dari rumah. Selanjutnya dilihat dari berbagai bakat siswa, serta daya serap masing-masing siswa, semuanya cukup bervariasi. Hal tersebut otomatis akan berdampak pada prestasi dan motivasi siswa di dalam kelas.

Pandemi Covid-19 adalah ancaman bagi semua orang di planet ini, serta darurat kesehatan manusia. Pandemi COVID-19 juga berdampak signifikan pada bidang pendidikan. Menurut artikel ABC News mulai 7 Maret 2020, beberapa negara telah menutup sekolah untuk mencegah penyebaran Covid-19. (tribunnews,14-15 juni 2020). Berdasarkan temuan tersebut, Indonesia berada dalam kondisi kesehatan kritis, dan diperlukan solusi yang tepat untuk menghentikan penyebaran COVID-19 agar aktivitas dapat kembali berjalan normal, khususnya di bidang pendidikan. Dampak Covid-19 pada pendidikan sangat besar, dan dirasakan oleh berbagai kalangan, termasuk instruktur, kepala sekolah, siswa, dan orang tua. Universitas dan perguruan tinggi lain, serta sekolah dasar, ditutup karena tingginya prevalensi COVID-19 di Indonesia. Dengan ditutupnya sekolah, pemerintah mengambil langkah-langkah untuk memastikan proses belajar tidak terganggu dan anak-anak tetap memiliki hak untuk belajar. Alhasil, langkah pemerintah selanjutnya adalah melanjutkan proses pembelajaran, namun kali ini secara online ketimbang tatap muka. (Simmons 2002).

Kata "guru" berasal dari kata India yang berarti "orang yang mendidik tentang pelarian dari rasa sakit." Guru yang menabung untuk menyemangati calon biksu di panti asuhan bhinaya dianggap sebagai "guru maharesi" dalam tradisi Hindu (tempat pendidikan biksu).

\section{METODE PENELITIAN}

Tujuan penelitian adalah menggambarkan pembelajaran daring yang diselenggarakan di SMP Taman Harapan Medan dalam upaya menekan mata rantai penyebaran Covid-19. Dalam penelitian ini, peneliti menggunakan penelitian kualitatif deskriptif. Penelitian kualitatif" didefinisikan sebagai "penelitian yang berusaha menjelaskan kejadian dengan mengumpulkan bukti sebanyak mungkin". Teknik pengumpulan data yang dipakai oleh peneliti adalah wawancara. Wawancara adalah interaksi antara dua orang atau lebih untuk memperoleh data yang akurat dari sumber, wawancara dilakukan untuk mengetahui tentang dampak Covid-19 terhadap pembelajaran di SMP Swasta Taman Harapan. Peneliti mencari publikasi di jurnal online menggunakan istilah "Dampak Covid-19" dan "Pendidikan" dalam pencariannya. Berbagai jenis 
informasi dan artikel ditemukan melalui pencarian dengan menggunakan kata kunci "Dampak Covid-19" dan "Pendidikan". Pembahasan mengenai dampak Covid-19 dan pendidikan tercakup dalam materi dan artikel pilihan. Artikel dan materi yang dipilih adalah mengenai dampak Covid-19 terhadap pendidikan (pembelajaran online). Informasi yang paling relevan diambil dari berbagai sumber.

\section{HASIL DAN PEMBAHASAN}

Tujuan dari penelitian ini adalah untuk melihat bagaimana Covid-19 mempengaruhi proses belajar guru dan siswa (siswa). Berikut adalah hasil wawancara dengan salah satu guru, berdasarkan wawancara yang dilakukan dengan tujuan untuk memperdalam data yang diperoleh di SMP Taman Harapan: "Bahkan dalam bidang ini, sejak berkembangnya wabah Covid-19 di Indonesia, saya merasakan berbagai dampak ketika proses pembelajaran online dilakukan, salah satunya adalah pembuatan RPP dengan sistem online, dimana saya (pengajarnya) saya dituntut untuk dapat melakukan pembelajaran online." Persiapan saya (sebagai guru) untuk pembelajaran online kurang memadai." Selain itu, guru di SMP Taman Harapan juga mengalami kendala fisik, sehingga sulit untuk menyampaikan materi kepada siswa. Karena keadaan psikologis dan kognitif setiap siswa adalah unik. Meskipun penggunaan zoom digital untuk memungkinkan guru dan siswa berinteraksi tatap muka, inilah masalahnya. Meskipun demikian, para guru dapat mengambil manfaat dari dampak pandemi. Hal ini berdasarkan wawancara yang telah dilakukan bahwa: "Namun, ada efek baik yang mungkin dimiliki guru, dan efek itu adalah instruktur bisa lebih kreatif dalam menggunakan perangkat pembelajaran berbasis teknologi."

Kegiatan yang melibatkan banyak orang, seperti kegiatan belajar di sekolah, kini dibatasi. Untuk mengurangi jumlah pasien yang terpapar Covid-19, pemerintah mengimbau masyarakat untuk melakukan aktivitas di rumah. Menteri Pendidikan Dan Kebudayaan Nadiem Anwar Makarim telah menerbitkan Surat Edaran Nomor 3 Tahun 2020 pada Satuan Pendidikan dan Nomor 36962/MPK.A/HK2020 tentang Pelaksanaan Pendidikan dalam Masa Darurat Coronavirus Disease(Covid-19), maka kegiatan belajar dilakukan secara daring (online) atau pembelajaran jarak jauh dalam rangka pencegahan penyebaran Coronavirus Disease (Covid-19).

Namun pemanfaatan teknologi bukan berarti tidak ada masalah, banyak juga kendala dan masalah yang menghambat efektifitas pembelajaran online, antara lain:

1. Keterbatasan Penguasaan TI (Teknologi Informasi) bagi Guru dan Siswa Persoalan yang muncul dari tugas-tugas teknologi informasi adalah tidak semua guru di Indonesia memahami cara menggunakan teknologi. (Andriani, 2015). Guru yang lahir pada sekitar tahun 1980 juga menjadi buktinya. Siswa yang situasinya mungkin hampir sama dengan guru dalam hal mengetahui penggunaan teknologi dibatasi dalam penggunaan media online karena keterbatasan teknologi informasi. Senada dengan penelitian Dewi (2020) bahkan beberapa guru senior memerlukan bantuan dan pelatihan sebelum mereka dapat menggunakan sumber daya atau fasilitas secara efektif untuk meningkatkan aktivitas pembelajaran online. 
Akibatnya, dukungan dan kolaborasi orang tua sangat penting untuk keberhasilan pembelajaran. Perlu terjalin komunikasi yang baik antara guru dengan sekolah dan orang tua.

2. Kerugian Siswa pada Proses Penilaian

Ketika sekolah tutup, anak-anak menderita kerugian yang signifikan dalam hal kehilangan siswa selama proses penilaian. Dalam keadaan normal, siswa dapat menyelesaikan banyak ujian sekolah dan negara; Namun karena dampak Covid-19, pertanyaan tersebut dibatalkan atau ditunda. Penilaian internal di sekolah mungkin kurang, meskipun informasi penilaian sangat penting untuk keluarga. Beberapa berpendapat bahwa informasi tentang murid ini juga penting untuk kelangsungan jangka panjang masa depan siswa. Anggap saja target skill atau keahlian tahun ini mendapatkan apa-apa, sehingga berdampak pada tahun berikutnya. Dampak ini juga dirasakan oleh para orang tua, terutama dalam hal tantangan yang mereka hadapi, seperti meningkatnya biaya pembelian kuota internet. karena dengan menggunakan teknologi online guru dan siswa juga membutuhkan koneksi jaringan kuota, tingkat penggunaan kuota internet akan meningkat, begitu juga dengan biaya orang tua. Hal ini sependapat dengan Syaharudin (Handayani et al., 2020) yang menyatakan bahwa efek dari pembelajaran online berkaitan dengan masalah teknis dan pembelajaran, seperti harga kuota internet, akses sinyal yang buruk, kurangnya pengetahuan dalam menggunakan aplikasi pembelajaran yang canggih, dan kurangnya partisipasi siswa saat pembelajaran online terjadi. Guru menemukan bahwa tidak semua siswa mampu menggunakan internet atau media sosial sebagai alat pembelajaran, dan beberapa guru senior tidak dapat menggunakan alat atau fasilitas untuk mendukung kegiatan pembelajaran online dan memerlukan pengawasan dan pelatihan. Akibatnya, kerjasama dan dukungan orang tua sangat penting untuk prestasi belajar. Komunikasi guru sekolah dengan orang tua siswa harus berjalan dengan lancar.

Fakta bahwa tidak semua guru memadai dalam menggunakan teknologi memiliki dampak yang signifikan terhadap guru. Guru harus mampu melakukan pembelajaran online; kompetensi guru dalam pemanfaatan teknologi berdampak signifikan terhadap kualitas pembelajaran dan hasil belajar siswa. Akibatnya, guru harus mengikuti pelatihan lebih awal agar siap memberikan pembelajaran online. Pengaruh lain bagi instruktur adalah bahwa, di masa lalu, guru belajar dengan berinteraksi langsung dengan murid untuk membiasakan mereka dengan keadaan. Namun, ketika dihadapkan dengan suasana belajar di rumah, guru menjadi bosan. Guru tidak memiliki kesempatan untuk bertemu dan berbaur dengan guru lain; sebaliknya, mereka sekarang harus mengajar di rumah. Maka dari itu, pihak sekolah harus memperhatikan hal tersebut, sekolah dapat memberikan motivasi kepada guru.

Jurnal Pendidikan dan Penelitian Guru bergantung pada internet dalam proses pembelajaran online, dan pengeluaran guru juga ikut meningkat. Karena tanpa akses internet, atau dalam situasi seperti ini, kuota internet, belajar tidak akan bisa dilakukan. Satu semester pembelajaran online membutuhkan penggunaan internet yang cukup besar. Untuk mempersatukan murid, komunikasi harus terus dilakukan, sehingga persaingan guru tidak hanya menghasilkan kuota 
internet, tetapi juga biaya untuk komunikasi dengan kepala sekolah, seperti kredit, dan kompetisi lainnya, seperti waktu. Guru akan meluangkan waktu untuk melakukan pelajaran dengan percaya diri. Dampaknya pada siswa Karena pandemi COVID-19, siswa harus belajar dari jarak jauh dan di rumah dengan bantuan orang tua mereka. Siswa tidak cukup siap sebagai akibat dari pandemi. Misalnya, kurangnya motivasi siswa untuk mengikuti pembelajaran online. Siswa yang terbiasa belajar secara berkelompok kini harus belajar sendiri di rumah sehingga menimbulkan kebosanan. Kemudian, setelah liburan yang terlalu lama, murid menjadi bosan dan ingin keluar rumah. Fasilitas yang tidak memadai menyebabkan siswa tidak puas dengan kesediaan mereka untuk terlibat dalam pembelajaran yang berisiko. Mahasiswa harus dihadapkan pada sistem online yang fokus pada pembelajaran berbasis teori. Dikarenakan wabah covid-19, siswa sering berlatih untuk topik yang menuntut latihan, meninggalkan teori saja untuk memberikan materi. Hal ini menyebabkan siswa lambat memperoleh informasi, apalagi jika dibandingkan dengan daya serap siswa yang beragam. Ada beberapa siswa yang cepat mengejar ketertinggalannya dalam belajar, tetapi ada pula yang lambat dalam mengasimilasi informasi sehingga menyebabkan mereka tertinggal dalam belajar. Mau tidak mau siswa harus menghadapi teknologi untuk mendukung pembelajaran akibat pandemi covid-19. Untuk mengembangkan bahan ajar untuk pembelajaran jarak jauh, sekolah harus menyediakan alat dan bahan. Siswa harus dihadapkan pada berbagai situasi belajar untuk menjadi pembelajar online yang baik (Zapalska 2006). Senada dengan Drago, ia menyatakan bahwa siswa yang mengikuti pembelajaran online memiliki gaya membaca, menulis, dan visual yang kuat (Drago 2004).

\section{KESIMPULAN}

Berdasarkan temuan penelitian dan pembahasan di atas, ditemukan bahwa penelitian yang dilakukan dengan teknik pengumpulan data dengan wawancara yang dilakukan pada guru di SMP Swasta Taman Harapan mengungkapkan bahwa proses pembelajaran yang digunakan guru telah berganti dari pembelajaran langsung ke pembelajaran online. Karena pembelajaran dilakukan dengan berani atau pembelajaran jarak jauh dilakukan di rumah, guru juga kurang ideal dalam memberikan materi pembelajaran, pembelajaran yang berani dirasa sangat tidak efektif bagi guru dan siswa. Sehingga membuat materi tidak lengkap dan penggunaan media pembelajaran dalam pembelajaran online juga tidak maksimal. Guru kurang ideal dalam memberikan materi pembelajaran karena pembelajaran dilakukan dengan berani atau pembelajaran jarak jauh dilakukan di rumah, dan pembelajaran yang berani dinilai sangat tidak efektif baik bagi guru maupun siswa. Akibatnya materi tidak lengkap, dan penggunaan media pembelajaran dalam pembelajaran online juga tidak efisien. Hal ini menyebabkan siswa menjadi tidak puas dengan pembelajaran online dan siswa juga akan merasa tidak puas dengan pemberian tugas sehari-hari. 


\section{REFERENSI}

Aji, R. H. S. (2020). Dampak Covid-19 pada Pendidikan di Indonesia: Sekolah, Keterampilan, dan Proses Pembelajaran. Salam: Jurnal Sosial dan Budaya Syar-i, 7(5), 395-402.

Baharuddin, M. R., \& Sulestry, A. I. (2019). Development of Geometry Books Based on Behavioristic Theory. In International Conference on Natural and Social Sciences (ICONSS) Proceeding Series (pp. 281-284).

Andriani, T. (2015). Sistem pembelajaran berbasis teknologi informasi dan komunikasi. Jurnal Sosial Budaya, 7(2), 127-150.

Dewi, W. A. F. (2020). Dampak Covid-19 terhadap Implementasi Pembelajaran Daring di Sekolah Dasar. Edukatif : Jurnal Ilmu Pendidikan, 2(1), 55-61.

Fitriani, F., Baharuddin, M. R., \& Kayanti, J. (2019, October). Comparison of Cooperative Learning Model Think Pair Share and Think Pair Square Toward Students' Mathematical Communication Ability. In International Conference on Natural and Social Sciences (ICONSS) Proceeding Series (pp. 202-208).

Handayani, T., Khasanah, H. N., \& Yoshinta, R. (2020). Pendampingan Belajar Di Rumah Bagi Siswa Sekolah Dasar Terdampak Covid-19. ABDIPRAJA (Jurnal Pengabdian Kepada Masyarakat),

Junaid, R., \& Baharuddin, M. R. (2020). Peningkatan Kompetensi Pedagogik Guru melalui PKM Lesson Study. To Maega: Jurnal Pengabdian Masyarakat, 3(2), 122-129.

Kaler, C. B. (2012). A Model of Successful Adaptation to Online Learning for College-Bound Native American High School Students. Multicultural Education \& Technology Journal.

Mirzaqon, A.(2018). Studi Kepustakaan Mengenai Landasan Teori Dan Praktik Konseling Expressive Writing Library. Jurnal BK UNESA, 1, 1-8

Moh. Roqib, dan Nurfuadi. 2011.Kepribadian Guru. Purwokerto: STAIN press. 